\title{
The Level Of Education Is Able To Determine The Behavior Of The Use Masks As A Prevention Of Coronavirus Disease 2019 in the City of Batam Kepulauan Riau
}

\author{
Victor E. D Palapessy ${ }^{1 *}$, Muhammad Rakib Latuconsina ${ }^{2}$, Sahrir Sillehu ${ }^{3}$ \\ ${ }^{1}$ Akademi Kesehatan Kartini Batam \\ ${ }^{2}$ Fakultas Ilmu Administrasi, Universitas Brawijaya \\ ${ }^{3}$ STIKES Maluku Husada \\ *Corresponding Author: \\ Email: victor_palapessy@yahoo.com
}

\begin{abstract}
.
Cases of covid-19 in Indonesia, first appeared on June 02 March 2020 as much as 2 cases. In May 2020, the number of deaths is still rising despite also cure the patient. Until September 11, 2020, the case of positive covid-19 increased by as much as 3.737. So a total of 210.940 people. While for the case of recovery, there are the addition of as much as 2.707 the person bringing the total to 150.217 people. Then for patients who died increased to 88 people so that the total of patients who died 8.544 people (Compass, 2020). One way the most easy to do to prevent the virus's spread in the community is to use a mask, but still often seen there are some people who go without using a mask. The purpose of this study is to determine the influence of age, gender, education, employment status, type of mask of the behavior of the use of masks as a prevention of coronavirus disease 2019 in the City of Batam. This Research is a quantitative research, using the approach of the study cross sectional. The sample in this study as many as 100 respondents. The instrument used was a questionnaire. Data analysis in this study using SEM PLS. The results of the research showed that gender, type of mask, education, employment status and age have a positive and significant impact on the behavior of use of the mask. The variables that most influence the variable behavior of the use of the mask that the education variable $(0,316)$, employment status $(0,275)$, age $(0,216)$, gender $(0,212)$, and the type of mask (to 0.149). Education last owned by a person can affect the behavior of existing in itself, in this case associated with the use of the mask.
\end{abstract}

Keywords: Age, sex, education, employment status, type of mask, the behavior of the use of masks.

\section{INTRODUCTION}

WHO (World Health Organization) has set the status of the coronavirus disease 2019 become a pandemic in the world, since March 11, 2020. Covid-19 is the disease resulting from the corona virus. This disease is a new type that is found in the year 2019 and never identified attacked a human before (Keliat, 2020). Pandemic covid-19, this is the spread the coronavirus disease 2019 in the whole world and until the month of April 2020 has infected more than 210 countries (WHO, 2020). Corona Virus first infected in the province of Wuhan, China. The beginning of his appearance in thought is a disease of pneumonia, because the symptoms are similar to flu in general. But the fact is different, corona virus is growing faster then become severe infection, organ failure and lead to death. Emergencies can occur in patients who have health problems before (Mona, 2020).

The spread of corona virus globally, still continue to accrue from day to day. On 12 March 2020, the total cases of covid 19 in the world confirmed as much as 28.637 .392 (28.6 million) cases. Of these, as much as 20,560,079 (20.5 million) the patient has healed, and 918.890 people died. Active cases to date as much as 7.158.445 with details 7.097.436 patients with mild conditions and 61.009 in a serious condition (Compass, 2020). Cases of covid-19 in Indonesia, first appeared on June 02 March 2020 as much as 2 cases. In May 2020, the number of deaths is still rising despite also cure the patient. Until September 11, 2020, the case of positive covid-19 increased by as much as 3.737. So a total of 210.940 people. While for the case of recovery, there are the addition of as much as 2.707 the person bringing the total to 150.217 people. Then for patients who died increased to 88 people so that the total of patients who died 8.544 people (Compass, 2020). 
Scientists and medical personnel around the world have conducted research in an effort to overcome the disease corona virus or coronavirus disease 2019 (covid-19), which is still widely spread. The best way for the prevention of the spread of this virus is to break the chain, such as isolation, early detection and protection, namely the basic wash hands with running water and soap, use hand sanitizer, use a mask and not touching the area of the face before washing hands, and then apply the ethics of coughing and sneezing with a better (Kemenkes RI, 2020). Because until now there is no vaccine specific for infection viris corona is because it is still in the stage of research (WHO, 2020).

The behavior is the actions of a person that can be learned and observed by an outside party. And age, gender, education, occupation are all factors that can affect human behavior (Notoatmodjo, 2017). The use of masks is a series of comprehensive measures to prevent and control that is useful to limit the spread of the disease-a viral disease of the respiratory tract, including covid-19. The mask can be used to protect a healthy person (used to protect yourself when in contact with an infected person) or to control resources (used by the infected person to prevent the transmission of more) (WHO, 2020). See the increasing number of patients with covid-19 from day to day then attempt the prevention of covid-19 continues to evolve to adjust to conditions there. At the beginning of the emergence of covid-19 is the use of masks intended only for health care workers and sick people or in the process of healing. But at this time the use of masks is already required for all people. (Ministry of health, 2020). This is done to prevent the virus from spreading in the community, but still often seen there are some people who go without using a mask, so that it then becomes interesting for the author to know how the influence of age, gender, education, employment status, type of mask of the behavior of the use of masks as a prevention of coronavirus disease 2019 in the City of Batam.

\section{METHODS}

This research type is quantitative, using the approach of the study cross sectional. Performed on the entire community of batam which crosses the academy of health kartini Batam and aged above 20 years, on 19 September 2020, as many as 100 respondents. In this research, the instrument of data collection in the form of a questionnaire that included age, gender, education, employment status, type of mask and the behavior of the use of masks. Operating procedure starts with the selection of the respondents in accordance with the criteria of the study and provide research information to the respondents clearly. To answer the hypothesis, this study uses data analysis using SEM PLS.

\section{THE RESULTS OF THE RESEARCH}

Characteristics Of Respondents

Characteristics of respondents includes age, gender, education, employment status, type of mask and the behavior of the use of masks.

Table 1.1 Characteristics Of Respondents

\begin{tabular}{lcc}
\hline \multicolumn{1}{c}{ Variable } & Number & Percentage (\%) \\
\hline Usia & 30 & 30 \\
>35 year & 70 & 70 \\
20-35 year & 39 & 39 \\
\hline Gender & 61 & 61 \\
Male & & \\
Women & 20 & 20 \\
\hline Education & 80 & 80 \\
SD or SLTP & 35 & 35 \\
SLTA or PT & 65 & 65 \\
\hline Employment Status & & \\
Does Not Work & & \\
& & \\
\hline Types Of Masks & & \\
\hline
\end{tabular}




\begin{tabular}{lcc}
\multicolumn{1}{c}{ Variable } & Number & Percentage (\%) \\
\hline Cloth Mask & 69 & 69 \\
Medical Mask & 31 & 31 \\
\hline Notice The Use Of Masks & & \\
No & 28 & 28 \\
Ya & 72 & 72 \\
\hline
\end{tabular}

Based on table 1.1 above, it is known that the majority of the respondents aged $20-35$ years (70\%), genderless female $(61 \%)$, educated SLTA/PT $(80 \%)$, work $(65 \%)$, using a mask fabric $(69 \%)$ and the Behavior of the use of the mask $72 \%$.

R Square

Table 2. R Square

\begin{tabular}{|l|r|r|}
\hline & \multicolumn{1}{|c|}{$\boldsymbol{R}$ Square } & $\boldsymbol{R}$ Square Adjusted \\
\hline $\begin{array}{l}\text { The Behavior Of The Use } \\
\text { Of The Mask }\end{array}$ & 0.562 & 0.539 \\
\hline
\end{tabular}

Based on table 2. above it is known that the r-square value of the variable behavior of the use of the mask of 0.562. It can be concluded that the influence of age, gender, education, employment status, type of mask of the behavior of the use of the mask of $56.2 \%$.

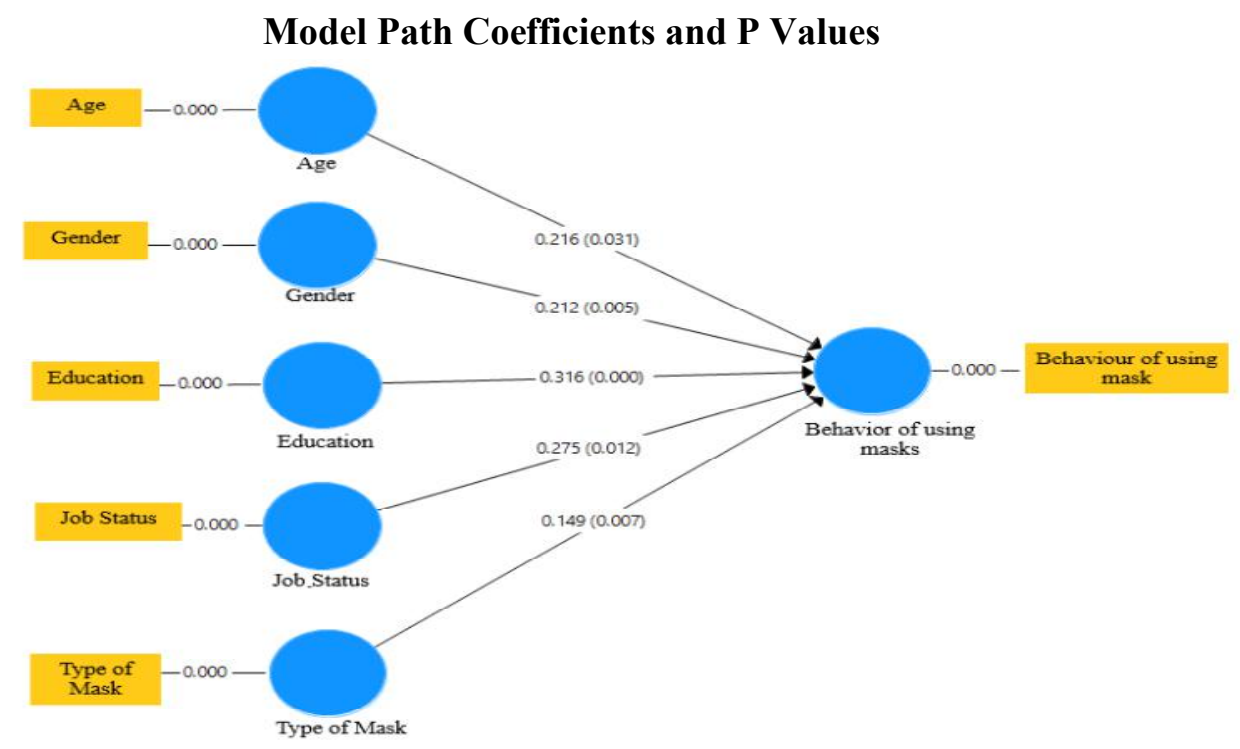

Fig 1. Model Path Coefficients and P Values

\section{The Results Of Hypothesis Testing}

Table 3. Results Of The Hypothesis Test

\begin{tabular}{|l|c|c|}
\hline & Original Sample (O) & $\begin{array}{c}\boldsymbol{P} \\
\text { Values }\end{array}$ \\
\hline Gender -> Notice The Use Of Masks & 0.212 & 0.005 \\
\hline Type Of Mask -> Notice The Use Of Masks & 0.149 & 0.007 \\
\hline Education -> Notice The Use Of Masks & 0.316 & 0.000 \\
\hline Employment Status -> Notice The Use Of Masks & 0.275 & 0.012 \\
\hline The Age -> Notice The Use Of Masks & 0.216 & 0.031 \\
\hline
\end{tabular}

Based on table 3. be aware that the sex positive and significant effect on the behavior of use of the mask $(p=0.005)$. The value of the Original Sample (Path Coefficient) of 0,212 shows the direction of the relationship positive. This type of mask has positive and significant effect on the behavior of use of the mask $(p=0.007)$. The value of the Original Sample (Path Coefficient) equal to 0.149 shows the direction of the 
relationship positive. Education has positive and significant effect on the behavior of use of the mask $(p=0.000)$. The value of the Original Sample (Path Coefficient) of 0,316 shows the direction of the relationship positive. The Status of the work of influential positive and significant impact on the behavior of use of the mask ( $\mathrm{p}=0.012$ ). The value of the Original Sample (Path Coefficient) of 0,275 shows the direction of the relationship positive. Age and significant positive effect on the behavior of use of the mask ( $\mathrm{p}=0,031)$. The value of the Original Sample (Path Coefficient) of 0,216 shows the direction of the relationship positive.

Nilai path coefficients menunjukkan besar pengaruh variabel bebas terhadap variabel terikat. Secara berurutan variabel bebas yang paling berpengaruh terhadap variabel perilaku penggunaan masker yaitu variabel pendidikan $(0,316)$, status pekerjaan $(0,275)$, usia $(0,216)$, jenis kelamin $(0,212)$, dan jenis masker $(0,149)$.

\section{DISCUSSION}

The statistics show that age, gender, education, status of the mask and the mask type to affect the behavior of the use of masks.

Someone who is younger, is still receptive to new information that he knew to react to it. Another study conducted by Apriluana, et al (2016) show that there is a relationship between the age of the behavior of the use of PPE in health workers in RSUD Banjarbaru with $p$ value (of 0.006).

The gender of respondents is dominated by women, in some cases women are more meticulous when compared with men. Different is the case with the research that has been done by Apriluana, et al (2016) which states that there is no relationship between the gender of the nurse with the use of PPE with $p$ value $(0,940)$. High education person it will be increasingly easy to get some information, and absorb the information so that he understands to determine and take the decision of how he should react to it. Devi, et al (2020), says that the knowledge of good society affect the compliance in the use of the mask ( $\mathrm{p}=0.004)$.

Someone who works in the economy can be quite in fulfillment of his needs day-to-day and more friends around it works so it's easy to get new information. As research conducted by Lulut (2018) found that there is a relationship between employment status with the behavior of the mother in the fulfillment of nutrition ( $\mathrm{p}=0.001$ ). More people to employ the use of cloth masks amid the pandemic at this time, given the cheaper price compared with a surgical mask but the use of cloth masks are less effective in preventing the transmission of covid-19 if there has 3 layers and can be the last option.

\section{CONCLUSION}

Age, gender, education, employment status and type of mask positive and significant effect on the behavior of use of the mask. And in this research, the education variable is a factor that greatly affects a person's behavior in the use of masks.

\section{REFERENCES}

[1] Apriluana, Gladys., Khairiyati, Laily., Setyaningrum, Ratna. (2016). Hubungan Antara Usia, Jenis Kelamin, Lama Kerja, Pengetahuan, Sikap Dan Ketersediaan Alat Pelindung Diri (APD) Dengan Perilaku Penggunaan APD Pada Tenaga Kesehatan. Jurnal PublikasiKesehatan Masyarakat Indonesia, Vol. 3 No. 3, Desember 2016.

[2] Direktorat Jenderal Pencegahan dan Pengendalian Penyakit Kementrian Kesehatan RI. (2020). Pedoman Kesiapsiagaan Menghadapi Corona Virus Disease (COVID-19). Jakarta

[3] Keliat BA. (2020). Dukungan Kesehatan Jiwa dan Psiko Sosial (Mental Health and Psychososial Support) Covid-19 : Keperawatan Jiwa, IPKJI, Bogor

[4] Kementerian Kesehatan. (2020). Mencegah Penularan Covid-19 Dengan Gerakan Semua Pakai Masker. Direktorat Promosi Kesehatan Dan Pemberdayaan Masyarakat. Diakses tanggal 25 Juli 2020 jam 16.45 WIB.

[5] Kompas.com. (2020). Update Corona di Dunia 12 September : 28,6 Juta Orang Terinfeksi, Kasus Melonjak tapi Perancis Enggan Lockdown, diakses tanggal 18 September jam 11.15 WIB.

[6] Subekti, Luhut. (2018). Hubungan Status Pekerjaan Dengan Perilaku Ibu Dalam Pemenuhan Gizi Berdasarkan Kebiasaan Sarapan. Fakultas Ilmu Kesehatan Universitas Muhammadiyah Ponorogo.

[7] Pramita sari, Devi dan Sholihah, Nabilah. (2020). Hubungan Antara Pengetahuan Masyarakat Dengan Kepatuhan Penggunaan Masker Sebagai Upaya Pencegahan Penyakit Covid-19 di Ngronggah. Jurnal Ilmiah Rekam Medis dan Informatika Kesehatan, Vol. 10 No.1, Februari 2020. 
[8] WHO. (2020). Anjuran Mengenai Penggunaan Masker Dalam Konteks Covid-19. Panduan Interim 5 Juni 2020. https://www.who.int/docs/default-source/searo/indonesia/covid19/anjuran-mengenai-penggunaan-masker-dalamkonteks covid-19-june-20.pdf?sfvrsn=d1327a85_2

[9] WHO (2020). Coronavirus Disease (Covid 19) Situation Report-114, Agustus, 2020 